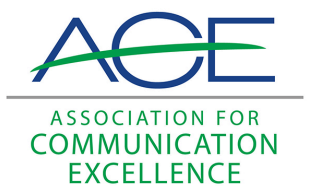

Journal of Applied Communications

\title{
Communication Responsibilities of the International Agricultural Research Centers; Designing a Program Viewers Remember; Get the Facts, Not the Chicken: How to Use and Instructional Film; Precision Journalism; News Writing
}

Paul Gwin

Annette Sanders

Orrine Gregory

See next page for additional authors

Follow this and additional works at: https://newprairiepress.org/jac

(c) (i) (-)

This work is licensed under a Creative Commons Attribution-Noncommercial-Share Alike 4.0 License.

Recommended Citation

Gwin, Paul; Sanders, Annette; Gregory, Orrine; and Lofstrom, Joyce (1981) "Communication Responsibilities of the International Agricultural Research Centers; Designing a Program Viewers Remember; Get the Facts, Not the Chicken: How to Use and Instructional Film; Precision Journalism; News Writing," Journal of Applied Communications: Vol. 64: Iss. 1. https://doi.org/10.4148/ 1051-0834.1780

This Review is brought to you for free and open access by New Prairie Press. It has been accepted for inclusion in Journal of Applied Communications by an authorized administrator of New Prairie Press. For more information, please contact cads@k-state.edu. 


\title{
Communication Responsibilities of the International Agricultural Research Centers; Designing a Program Viewers Remember; Get the Facts, Not the Chicken: How to Use and Instructional Film; Precision Journalism; News Writing
}

\author{
Abstract \\ Reviews of "Communication Responsibilities of the International Agricultural Research Centers," \\ published by Agricultural Developmenl Council, Inc., and the International Rice Research Institute (IRRI); \\ "Designing a Program Viewers Remember," by Gary A. Witt; and "Get the Facts, Not the Chicken: How to \\ Use and Instructional Film," by Gary A. Witt; Precision Journalism, by Phillip Meyer; and News \\ Writing<,em>, by George A. Hough III. \\ Authors \\ Paul Gwin, Annette Sanders, Orrine Gregory, and Joyce Lofstrom
}




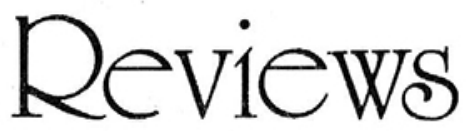

Includes reviews of articles and books on practical communications and on communications training. Send reviews of 1 or 2 typed pages to Jim Shaner, 1-98 Agriculture Building, University of Mlssourl-Columbla 65211.

"Communication Responsibilities of the International Agricultural Research Centers"' Published by Agricultural Development Council, Inc., and the International Rice Research Institute (IRRI), P.O. Box 933 Los Banos, Laguna, Phillipines.

Some much needed and well thought out guidelines for communication programs at international agricultural research centers are in this summary of a conference held at IRRI in the Philippines. It was attended by communicators from all 13 international agricultural research centers. The conference included four international center directors, 14 communicators from universities, and a sprinkling of scientists, training officers, and extension specialists.

The soundness of the emerging guidelines, we'd like to think, are due to some well known ACE members, whose names appear on the roster of delegates, i.e. Jim Bemis, CIMMYT (in Mexico); Francis Byrnes, IADS (New York); Tom Hargrove, IRRI; Grant Johnson, AVRDC (in Taiwan), formerly on Nebraska staff; Bryant Kearl, Wisconsin; Bob Kern, lowa; Walt Rockwood, IRRI; and John Woods, U.N. Development Training and Communication Planning, head, Asia branch, Bangkok, formerly of the Illinois editorial staff.

Delegates split into five work groups to make recommendations on: Facilitating Scientist-to-Scientist Information Flow; Keeping Donors, Policy Makers, and the Public Informed; Training, Support, and Development of National Communication Staff; Communication Research and Evaluation; and Communication Relationships with National Agricultural Programs. 
The report is well edited-right down to the bare essentials for communication planning in each of these communication service areas. The document should be a big help to editorial staffs of the international centers in explaining to administrators the need to broaden the center's communication reach.

Older ACE members can appreciate such recommendations as getting away from publishing the huge annual report summarizing all the research projects of the centers. Instead, the committee suggests converting to means of reporting to each specialized audience on progress in their own field of interest. It took a long time to bring some of our deans around to this way of thinking.

In the beginning, when there wasn't much research to report, it was probably good strategy to bulk it in a big fancy package, giving the impression of a heavy research contribution. But there is little of real interest to any one person in these weighty tomes, and they sound alike from one year to the next.

In their formative years, the centers were wrapped up in internal and scientist-to-scientist communication. Now that they have developed many adapted crop and livestock varieties and systems they are feeling the urge, as well as pressure from the outside, to make more effort to get their information to people who can use it.

Paul Gwin University of Missouri-Columbia

"Designing a Program Viewers Remember." Gary A. Witt. Educational and Industrial Television. Vol. 12, No. 12, December 1980, pp. 27-30.

Anyone involved in designing an instructional training program would do well to place a copy of this article into their production notes. In a series of succinct stepby-step guidelines, the author presents a basic informational program structure designed to make certain the audience gets and keeps your message.

The article goes beyond the traditional program planning format of needs analysis, content outlines, and production schedules. Instead it expands on the viewers' needs and limitations during the learning

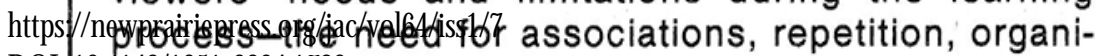
DOI: $10.4148 / 1051-0834.1780$ 
zation and for time for incorporation, for example.

The eight guidelines are presented in commonsense terms of what is known (but seldom used) about the psychology of learning. Explanations and discussion follow each guideline, helping you to translate research findings into actions. For example, the guidelines tell you how to get the viewers ready to learn and how to help them remember more.

Guidelines include: (1) designing the production according to your audience and goal, (2) telling the viewers what's coming and what you expect them to do and learn, (3) associating new facts and ideas with ones the viewers already know, (4) utilizing visual and mental imagery, (5) trimming the program to avoid learning "overload," (6) giving the viewer time for information to "sink in," (7) using repetition for critical facts, and finally, (8) presenting a closing review of major points in an organized hierarchy. These guidelines are useful for teaching factual information, but are not directly applicable for teaching motor skills (such as how-to-drive a nail, or milk a cow), abstracts or concept learning (such as energy conservation) or for getting people to change attitudes. In each of these other categories of learning, the learner's needs vary, and are not addressed in the article.

Although the eight guidelines sound familiar to many of us, and we've probably had the feeling they ought to work, we may not use them when we should. Articles such as this can help us understand why they are important, and why we should do all of them every time we prepare an informational program. According to the author, benefits from doing so are (1) higher viewer recall, (2) simpler, shorter, more interesting programs and (3) improved cost-effectiveness.

Instructional communicators often have at their fingertips detailed instructions concerning the "nuts and bolts" of programming-how to use the camera, for example, or prepare a content outline. But seldom is a blueprint available for the all-important "giant step" of translating content into a useful program. This article should certainly be helpful for those of you about to take such a "giant step." Although primarily written from the viewpoint of a video programmer, the guide- 
lines are appropriately transferable to other presentation formats such as lectures, slide-tapes, or overhead transparencies. This article focuses on producing a learning program. The author expands on the media psychologist approach in using instructional programs (particularly films) in a separate article reviewed in this issue.

\section{Annette Sanders University of Missouri-Columbia}

"Get the Facts, Not the Chicken: How to Use and Instructional Film." Gary A. Witt. Media and Methods. Vol. 17, No. 4, December 1980, pp. 26-28.

The author introduces this article with the story of the elaborate film crew and production techniques that went into making an instructional film. Its purpose was to teach people in an underdeveloped country about boiling their water to prevent certain illnesses. When the final test came and the film was shown to a group of villagers, there was little response. It seems the only thing the villagers saw and remembered was a chicken that happened to run through the background of one scene. Why? They knew about chickens. They related to chickens. They didn't know about boiling water, so that wasn't important to them.

The author suggests that there are specific things to do both before and after showing an instruction film. These guidelines are based on information about how people learn, and not on the perceived needs and goals of the producer/institution. Taking off from eight guidelines for developing an effective program (mentioned in a separate article by the same author reviewed in this issue), the author develops a step-by-step sequence of eight specific actions to be taken when using an instructional program-specifically films.

These guidelines relate to learning by association. That is, the more linkages or associations we make between new information and that previously acquired, the more organized is our storage of that information. Consequently, the more effective our recall will be when we need to retrieve it. These associative guidelines are most applicable to films which teach facts and concepts. Other categories of films that teach motor

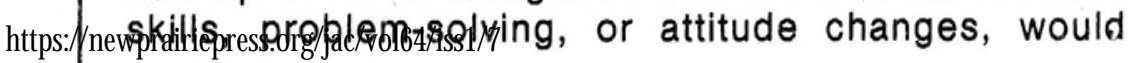


each require modified guidelines. These are not addressed in this article.

Before showing an instructional film, the author suggests you should (1) get the students ready for what they'll see, (2) point out the most relevant topics, (3) tell viewers how they'll be expected to use the information, (4) outline the major points of the film, and (5) peak their interest with post-viewing contests or "quiz" shows about the content.

After viewing the film (6) you should assist the viewers in making associations with things they already know about, (7) ask them to think of mental images or pictures that capture the main points of the film, and (8) group these major points into an organized summary for the viewers. Each guideline is explained and defended with theory and appropriate examples. But the research is translated into easy-to-understand and practical terms.

So, the next time you're asked to show a film to a group of agriculture specialists, or a $4-\mathrm{H}$ group, or a home economics extension meeting, for example, you might want to first read this article. Make sure your audience does get the facts, and "not the chicken."

Annette Sanders

University of Missouri-Columbia

Precision Journalism. Phillip Meyer, Indiana University Press, 1979, Second Edition.

Precision Journalism by Phillip Meyer, published by the Indiana University Press in 1979, is in its second edition. It is a good guide to using social science research methods in the field of journalism.

Meyer calls it a "starter kit"' for finding more intricate tools to standard journalism concepts, models and hypothesis testing of social science research more precisely define issues. Its survey methods more accurately represent all the public. And its statistical and computer tools can help journalists more accurately analyze the differences between the various peoples in our society regarding the social events and social issues that shape it. Meyer presents all this with clarity and easy reading examples.

As journalists, we are great users of anecdotes. However much they improve readability, we often gen- 
eralize without adequate or scientific analysis, according to Meyer.

He suggests the capacity to manage data has changed. Today pre-packaged programs make it easier for the computer to handle almost any instruction journalists might use.

For better results and more use of research in precision journalism, editors will need to develop in-house capability and to find the professional talent to use it. Meyer says projects still must be carefully thought through and financed (after almost endless discussion).

The author suggests journalists follow the example of the social scientists and give up the idea that a few facts and common sense will solve any problem. Reporters need to develop some new high-powered research techniques of their own. Quantification is not the tedious chore it used to be and Meyer capably shows how to simplify and sharpen up the research approach to reporting.

Orrine Gregory

University of Missouri-Columbia

News Writing, George A. Hough III, University of Georgia, Houghton Mifflin Co., 1980, \$13.95.

Most communicators agree that writing a news story is the best way to teach the techniques of news writing. True, there is no substitute for pounding out a story under deadline pressure. But when it comes to the basics of the art, News Writing (Houghton Mifflin Co., \$13.95), by George A. Hough III, covers news writing for the beginner.

This 1980 edition is an updated version of the author's 1975 text. A new chapter on news gathering notes the change in the acutal concept of news. Reporters now cover a specific subject or activity instead of only places. With the shift to sectionalization and survey research in newspapers, more communicators in agriculture and home economics will be part of the newspaper staff. The emphasis is on the process of news, instead of just an event. As Hough explains in the book, "...the idea of news gathering today is to treat news more broadly and follow it wherever it leads."

Because it deals with basics, News Writing looks at

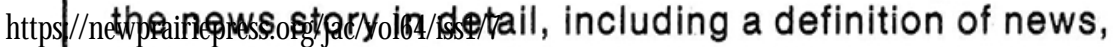


the five Ws, leads, grammar and punctuation, and rewriting and editing. It also covers the feature. Each chapter carries examples from actual newspaper stories.

The agriculture or home economics student in communication will find the chapter called "The Numbers Game" helpful for writing with statistics, such as in cost-of-living stories. Specific examples show how a writer can best inform the public about rising prices using the Consumer Price Index and other "numbers" sources.

The excerpts from the newspaper stories are also an advantage for the teacher. Most are from straight news stories but the techniques can still be applied to writing for agriculture or home economics. Teachers will find more of the feature story examples related to food, consumer economics or the family and thus more applicable to agricultural communications.

News Writing does include one chapter on grammar and punctuation entitled "Newspaper Language." Even with the best reporting, a communicator in any field who doesn't know sentence structure and punctuation, won't be able to turn out a good news story. It's admirable that Hough included the chapter and those with the time and interest might want to use Walsh's Plain English Handbook or another preferred grammar book with News Writing.

Students will find the style guide and glossary valuable tools for understanding the whys and hows of the news writing business. Many of the terms and guidelines are second nature to a seasoned writer, as the author himself points out. But when a student assigned a news story with a Washington dateline asks, "What is a dateline?" the need for these appendices is obvious.

News Writing is written by a journalist with experience as a reporter, editor and university professor. Used as a guide and a reference book, the text will be one for both teachers and students to keep on their library shelves. The author calls News Writing a "descriptive rather than prescriptive" book. It shows how writing is done and then leaves the followup of experience to the teacher and students. Joyce Lofstrom University of Missouri-Columbia 